\title{
The Market Structure of Securitisation and the US Housing Bubble
}

Susan Wachter

University of Pennsylvania

Follow this and additional works at: https://repository.upenn.edu/fnce_papers

Part of the Economics Commons, and the Finance and Financial Management Commons

\section{Recommended Citation}

Wachter, S. (2014). The Market Structure of Securitisation and the US Housing Bubble. National Institute Economic Review, 230 (1), R34-R44. http://dx.doi.org/10.1177/002795011423000104 


\title{
The Market Structure of Securitisation and the US Housing Bubble
}

\author{
Abstract \\ Housing finance and, specifically, the subprime private label securitisation market in the US, was at the \\ epicentre of the global financial crisis. Excessive debt expansion in the run-up to the crisis resulted in \\ credit risk, under-identified and mispriced ex ante, and in systemic risk. This paper considers the role of \\ financial innovation in debt markets and the changing market structure of securitisation in the evolution \\ of the US housing price bubble. New financing vehicles contributed to growing risk, but the more salient \\ factor was the change in the structure of securitisation, which led to unsustainable levels of debt. \\ Disciplines \\ Economics | Finance and Financial Management
}




\title{
WORKING PAPER
}

\section{The market structure of securitisation and the US housing bubble}

\author{
Susan Wachter ${ }^{*}$ \\ The Wharton School, University of Pennsylvania
}

Draft: Not for citation without permission of the author.

\begin{abstract}
Housing finance, and, specifically, the subprime private label securitisation market in the US, was at the epicentre of the global financial crisis. Excessive debt expansion in the run-up to the crisis resulted in credit risk, under-identified and mispriced ex ante, and in systemic risk. This paper considers the role of financial innovation in debt markets and the changing market structure of securitisation in the evolution of the US housing price bubble. New financing vehicles contributed to growing risk, but the more salient factor was the change in the structure of securitisation, which led to unsustainable levels of debt.

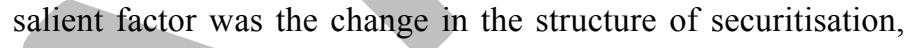

crisis
\end{abstract}
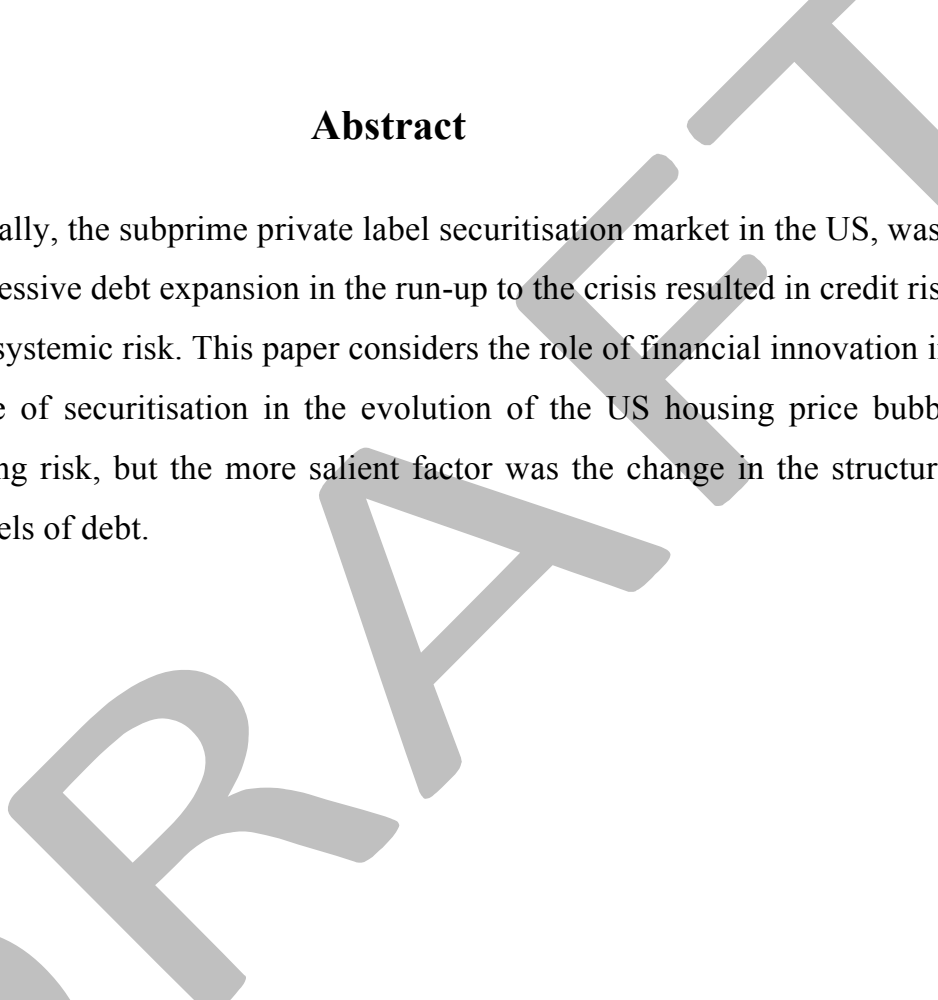

Keywords: mortgage securitisation; credit risk; housing bubble; housing finance

\footnotetext{
* Corresponding Author: Real Estate Department, The Wharton School, University of Pennsylvania, 430 Vance Hall, 3733 Spruce Street, Philadelphia, PA 19104, Email: wachter@wharton.upenn.edu, Telephone: (215) 898-6355. Dr. Wachter acknowledges the assistance from the Research Sponsors Program of the Zell/Lurie Real Estate Center at Wharton.
} 


\section{Introduction}

Housing finance was at the epicentre of the global financial crisis. In the US, housing finance expansion in the run-up to the crisis was followed by an increase in credit risk, which was neither priced nor identified, and in systemic risk. This is now well known; nonetheless the source of the crisis and the appropriate public policy response are still in question. This paper focuses on the role of financial innovation and the changing market structure of securitisation in the evolution of the housing bubble. ${ }^{1}$ New financing vehicles contributed to growing risk, but it is argued here that the more salient factor was the change in the structure of securitisation, which led to greater concentration of risk despite an apparent disaggregation of risk with an expansion in the number and variety of firms securitising housing finance.

In the US, the prevalence of fixed-rate mortgages requires a securitisation market-funding vehicle as opposed to bank balance sheet funding (Vickery and Wright 2013). The crisis unfolded in the US with an expansion of mortgage debt, funded by a rise in private label mortgage-backed securities, which were backed neither by the federal government nor by the originating banks. Thus, the debt increase occurred to a large degree in the "shadow banking system," with US banks apparently off-loading risky mortgages in an originate-to-distribute model. ${ }^{2}$ Simultaneous crises occurred in several European countries with mortgage debt expansion funded by debt for whose performance banks were to some degree contractually responsible; thus securitisation and the originate-to-distribute model are clearly neither necessary nor sufficient for a banking crisis (Wachter forthcoming) but they played a role in the crisis in the US. In earlier work Levitin and Wachter $(2012 ; 2013 a ; 2013 b)$ point to information failure, the failure to detect or price heightened credit default risk, a shift in market participants, and incomplete markets in real estate, as instrumental factors in the crisis. This article examines the role that a structural shift in the securitisation market played in this information failure and the resulting debt explosion in the US.

While usually thought of as a housing price boom and bust, the crisis could equally well be characterised as a credit boom and bust (Scheinkman 2013). The economic literature of the crisis has evaluated which run-up caused which, as noted below, but it is clear that the excessive expansion of debt put financial institutions' and households' balance sheets at risk. Concomitant with the house price run-up, an easing of borrowing conditions allowed an increase in borrowing 
for homeownership (Barakova, Calem and Wachter 2014) and refinancing of mortgage debt which drove loan to value (LTV) ratios to historically high and unsustainable levels.

While, as noted above, housing booms have occurred elsewhere without securitisation, debt expansion is a common feature of house price bubbles. The need for enhanced regulatory oversight of housing finance to limit potential systemic risk has been widely discussed. ${ }^{3}$ Debt bubbles expose the banking sector and the entire financial system to significant losses when house prices deflate and households default on their mortgages. ${ }^{4}$ In addition, declines in house prices have a negative impact on household consumption, especially among those households with high LTV ratios, negatively impacting economic activity and prolonging the aftermath of the crisis (Mian and Sufi 2014). The debt build-up is both instrumental to the price run-up and the bust.

But what is the form of the market failure that justifies regulation against the debt build-up? This question, along with the myriad pros and cons of policy reforms that have been offered, is still in contention, particularly in the US where the future of housing finance reform is in question. While it is accepted that securitisation and secondary market reforms are necessary to fund longterm mortgages and that the current reliance on a government funded secondary market is not an acceptable long-term outcome, as of this writing, securitisation market restructuring to escape the current reliance on government securitisation has stalled.

This article considers how the changing structure of securitisation markets contributed to the Great Financial Crisis in the US and examines the implications for securitisation reform. The article first documents the components of the extraordinary increase in securitisation-funded mortgage debt and then describes the changing structure of mortgage securitisation market in the run-up to the financial crisis. A schematic representation of the market is developed to illustrate the externality implications and, in conclusion, to inform directions for future reform.

\section{Mortgage debt and how it changed in the run-up to the crisis}

Houses are the largest assets held by the US household sector and mortgages are the largest liability (Federal Reserve Board, Flow of Funds). Mortgage markets are crucial for the housing market. In the 2000's, prior to the crisis, almost $90 \%$ of home purchases in the US were financed at least partially with debt. ${ }^{5}$ Debt became an increasingly important factor in housing during the 
housing boom from 1999-2006. Figure 1 plots the historical average combined loan to value ratio (CLTV) at origination for mortgages used to purchase homes. The average CLTV rose from the historically typical values of $80 \%$ to $90 \%$ at the housing price peak. During the housing bust mortgage leverage fell along with house prices. ${ }^{6}$

Figure 1. Historical CLTV at Origination (US average, purchase loans) and House Price

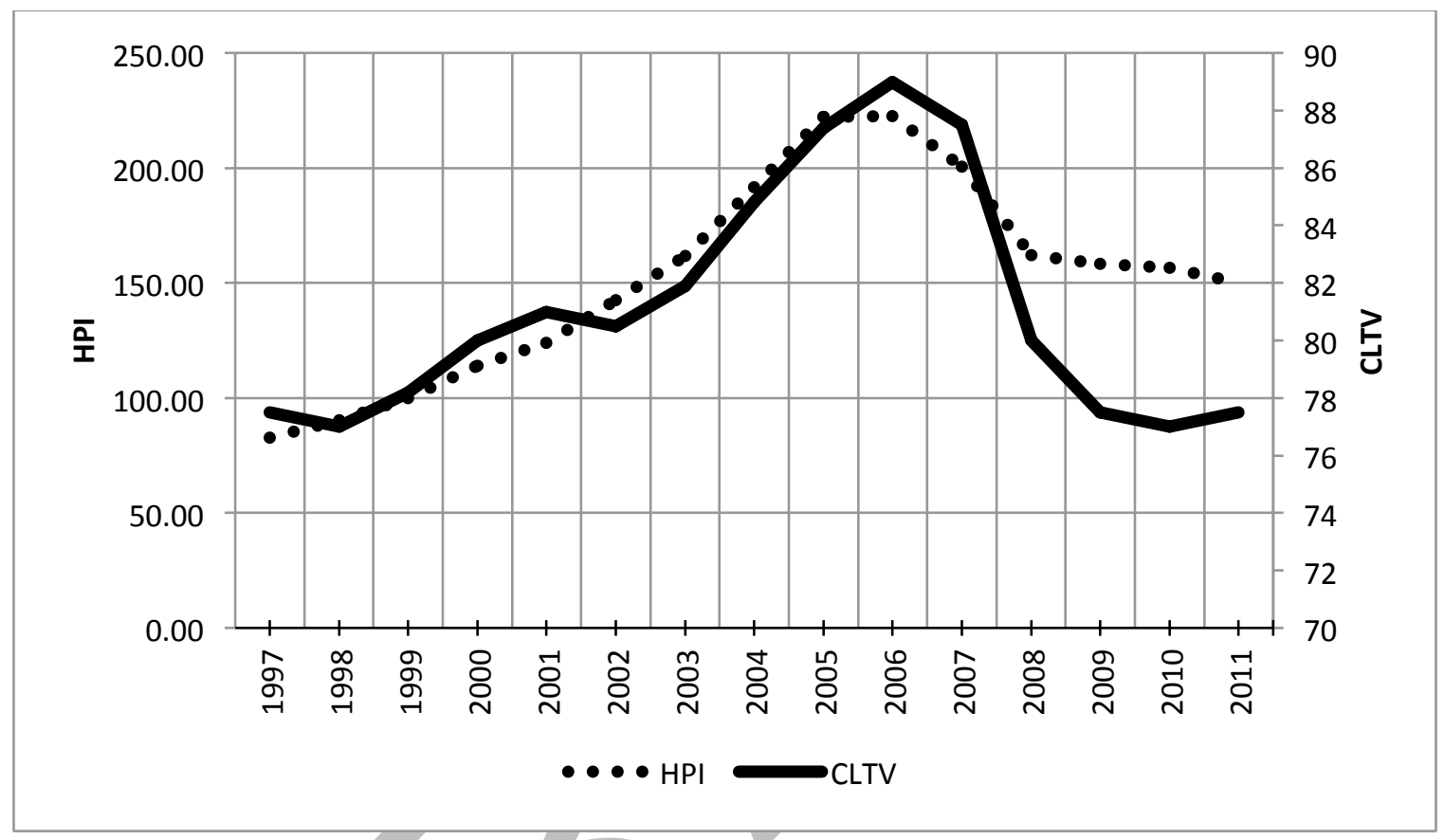

Note: Pre-2008: Non-agency loans, 2008-11: Agency loans.

Sources: Intex, Freddie Mac, AD\&Co., S\&P Dow Jones Indices LLC.

Not only did mortgage leverage go up during the boom but the types of mortgage contracts changed as well (Levitin \& Wachter 2012). Prior to the boom, most mortgages were selfamortising 30-year fixed-rate mortgages (FRMs). However, during the boom, there was a substantial increase in non-traditional mortgages (NTMs), including non-amortising (or negative amortisation) balloon and interest-only (IO) mortgage products, as well as subprime loans and Alt-A products (which do not require full documentation of income). Below, Figure 2 shows that the share of NTMs (including second mortgages) rose from $20 \%$ in 2003 to a peak of approximately $50 \%$ in 2006 , and nearly disappeared after 2008 . There was a simultaneous change in the types of products sold in the secondary market and a shift to private label securitization. 
Figure 2: Market Share of Non-traditional Mortgage Products and Private Label

\section{Securitisation}

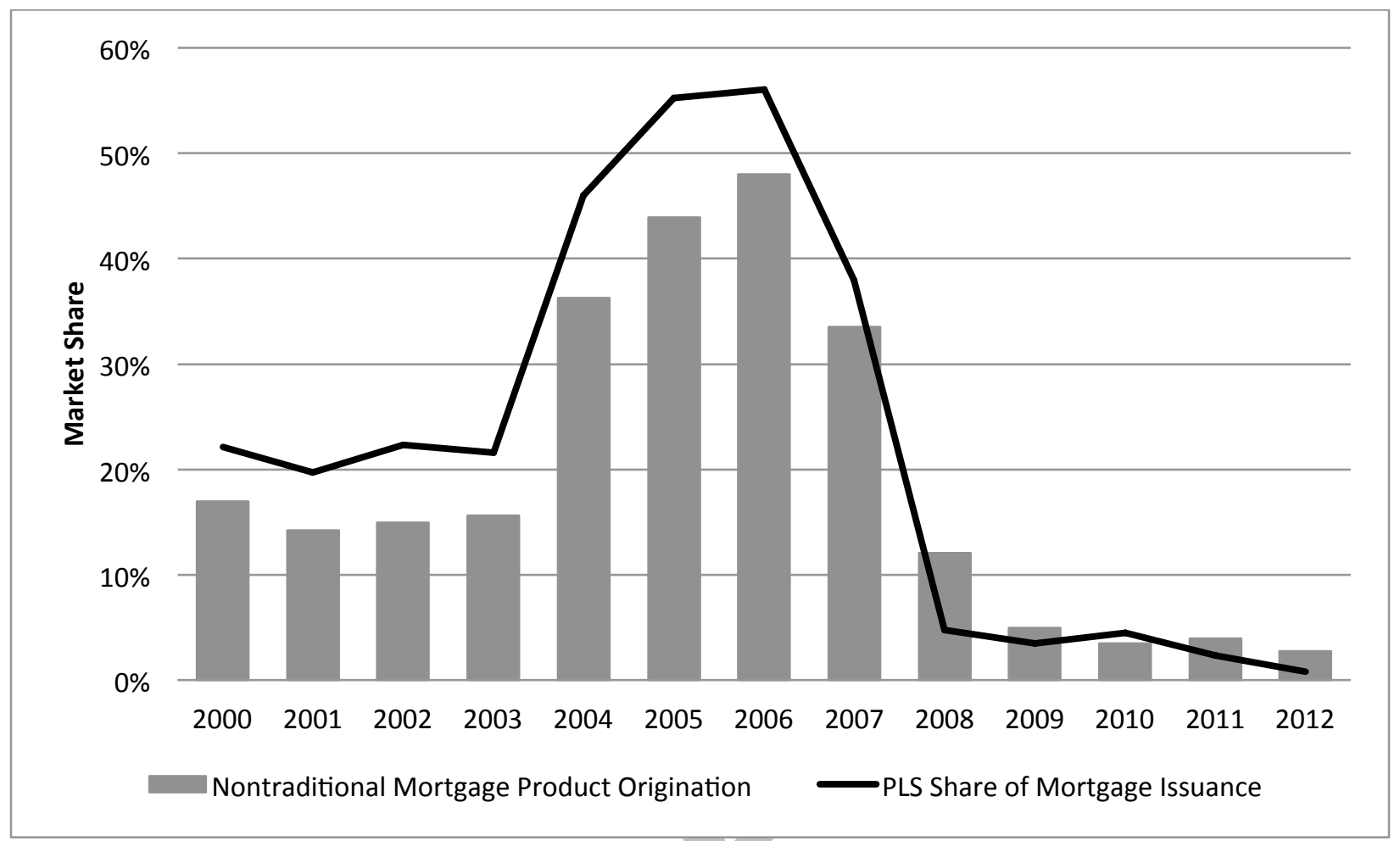

Note: Non-traditional mortgage products are subprime, Alt-A, and home equity loans.

Source: Inside Mortgage Finance 2013 Mortgage Market Statistical Annual.

While most conforming mortgages were securitised by the Government Sponsored Entities (GSEs), Fannie Mae and Freddie Mac, most NTMs were securitised in the private-label securitisation (PLS) market. Figures 2 and 3 (which disaggregates mortgages by type) show the share of PLS and NTM mortgage issuance peaking during 2006 and almost disappearing after 2008. While the PLS share rose during the housing boom, the GSE share (conventional conforming) shrunk before returning to levels over $60 \%$ post boom. ${ }^{7}$ 
Figure 3. Origination Shares by Mortgage Type, 2000-2012

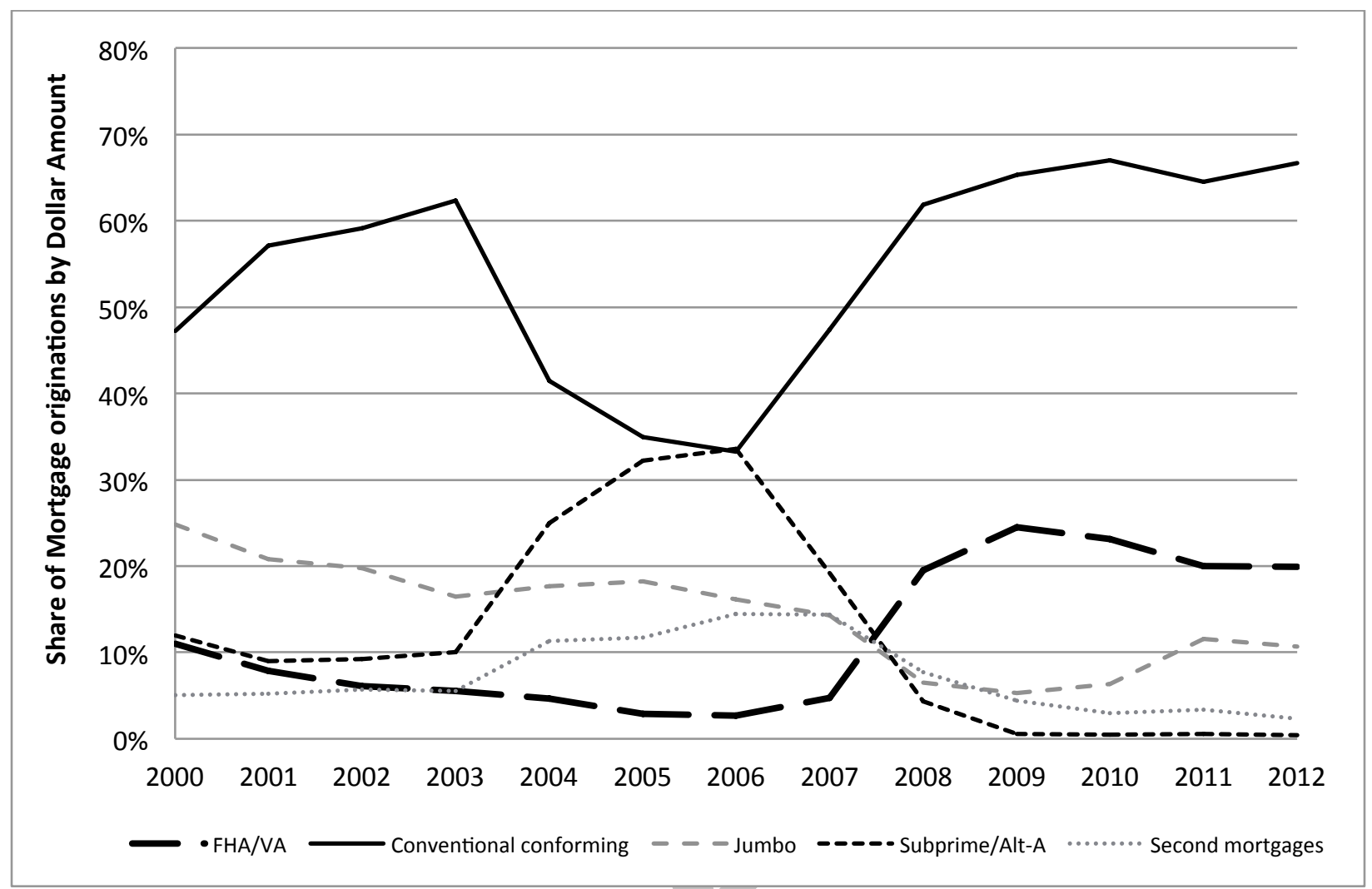

Source: Inside Mortgage Finance 2013 Mortgage Market Statistical Annual. 


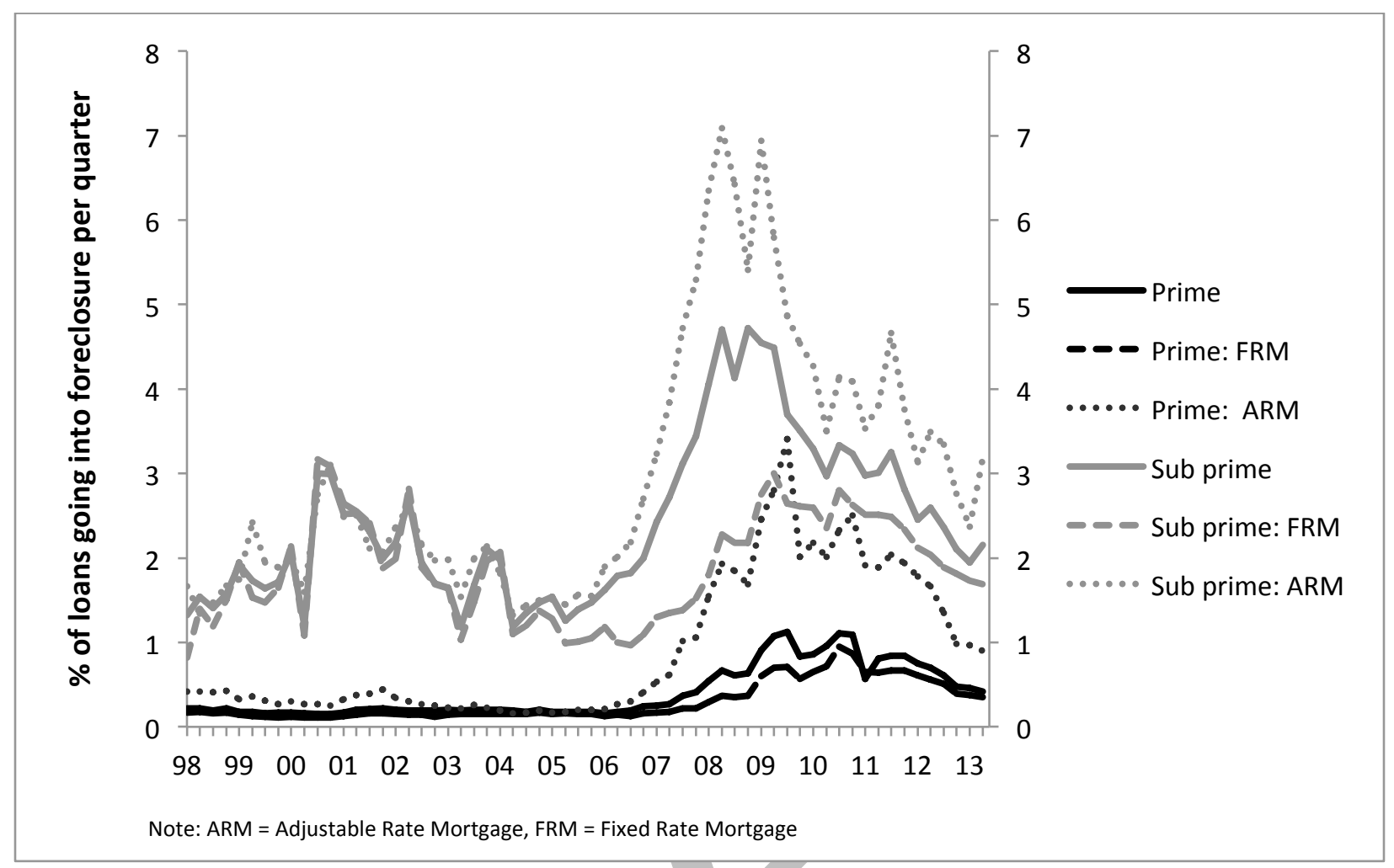

Source: MBA, Datastream, DB Global Markets Research.

The mortgage debt expansion played a crucial role during the financial crisis of 2007-2008 and the Great Recession because it linked the housing bust to the real economy. The bust in house prices that occurred after the peak in 2006, combined with the large amount of outstanding high leverage mortgages, led to an unprecedented rise in foreclosures. The data show that NTMs, funded by private label mortgage-backed securities, had historically high rates of default, and a far higher rate of foreclosure than other mortgage products. As shown in Figure 4, which provides data on the quarterly rate of foreclosure by market segment, subprime Adjustable Rate Mortgages (ARMs) had by far the highest foreclosure rate (almost 30\% annually at the peak). In addition to the shift to riskier mortgage products, there was a significant deterioration in underwriting of these loans (Anderson, Capozza, and Van Order 2011). The proliferation of AltA loans, which were eventually identified as so-called "liar loans", with unverified borrower income, was one striking illustration of this trend (The Financial Crisis Inquiry Commission 2011). ${ }^{8}$ The expansion of non-traditional mortgage products along with the deterioration of 
underwriting standards amplified the downturn. Households who had borrowed with these products faced greater risk of payment shocks, which coupled with negative employment shocks and price declines resulted in the extraordinary level of foreclosures. There is robust evidence that the shift in lending practices to lax underwriting and more risky products increased default risk (Anderson, Capozza and Van Order 2011).

Banks and other financial institutions suffered losses resulting from the wave of defaults. Subprime lenders went out of business and subprime and other forms of NTM credit went essentially to zero. Borrowers' losses drove the real economy to recession with lingering effects (Mian and Sufi 2014). The next section describes the role of the changing market structure of securitisation in the crisis and its historical antecedents and consequences.

\section{Mortgage securitisation structural change: antecedents and consequences}

The long-term fixed-rate self-amortising mortgage, the "American Mortgage" (Green and Wachter 2005), prevails in the US. This has been so since the Great Depression. Today, mortgage-backed securities once again finance these loans through government-backed entities. ${ }^{9}$ But it has not always been so. While fixed rate mortgages have prevailed since the Great Depression and secondary market institutions first evolved in this period, the financing of these mortgages has been subject to tectonic shifts, with new secondary market financing structures coming to prevail only after the failure of the previous system (Levitin and Wachter 2013c). Once again the structure of the secondary market is in question.

The structure of the institutions that shape the modern US housing finance system emerged in the aftermath of the Great Depression. Prior to this, the US mortgage market was dominated by adjustable-rate, short maturity loans with balloon payments. With the onset of the depression, as house prices declined, refinancing stopped, forcing borrowers who could not make the balloon payments to default, resulting in fire sales. In response to the failure of the mortgage market, the Federal Housing Administration (FHA) was established to insure and Fannie Mae was created to purchase, long-term self-amortising fixed rate FHA-insured mortgages, establishing these as the standard (Green and Wachter 2005). ${ }^{10}$ 
While FHA and broadly similar conventional loans predominated until the late 1960s, Fannie Mae accounted for only $10 \%$ of the funding market. Deposit-taking institutions, commercial banks and savings and loans (S\&Ls), represented the bulk of the market, funding long-term mortgages on their balance sheets with short-term deposits. Between the mid-1960s and the 1980s, worsening inflation led to interest rates on Treasury bonds above the interest rates offered by depository institutions, causing outflows of funds that worsened over time, eventually leading to the decapitalisation of the S\&Ls in the crisis of the 1980s (Levitin \& Wachter 2013c). At this point, the GSEs' market share grew dramatically.

The form of securitisation through the GSEs changed, along with their growing market share. ${ }^{11}$ In 1970, the Federal Home Loan Mortgage Corporation (Freddie Mac) was created to provide a secondary market for S\&L mortgages. Both Fannie Mae and Freddie Mac were limited to purchasing loans that were no greater than a statutory "conforming loan" size. Contrarily to Fannie Mae, which funded its purchase of mortgages by issuing bonds, Freddie Mac engineered a new instrument to fund its operation: mortgage-backed securities (MBS), issuing the first in 1971 , that pass through the payment streams from a pool of mortgages directly to investors. ${ }^{12}$

The development of MBS reinforced the standardisation of underwriting practices in order to produce relatively homogenous mortgages with regard to their interest rates and credit and prepayment risk profile, enabling them to be pooled efficiently through the "to be announced" (TBA) market for Agency MBS, creating a liquid secondary market (Vickery and Wright 2013). ${ }^{13}$

As securitisers, the GSEs enforced underwriting standards that maintained the integrity of their mortgage pools. They were incentivised to do so because they bore the credit risk on these mortgages and they were also subject to regulations that directly limited the type of mortgages they could purchase. Their demand was limited to conventional conforming mortgages for the GSEs and to mortgages that fit the FHA/VA standards for Ginnie Mae. ${ }^{14}$ The GSEs could only purchase loans below the conforming size limit established yearly by OFHEO, their regulator, and had to require credit enhancement in the form of private mortgage insurance (PMI) for loans with LTV ratios greater than $80 \%$ LTV. The GSEs were subject to the same regulations, limiting the potential for a "race to the bottom," which enabled them to enforce their standards on the originators. ${ }^{15}$ The combination of standard underwriting, government insurance and the 
emergence of a liquid secondary (TBA) market supporting these contributed to a low cost of funding for mortgage issuers.

Starting in the late 1990s, competition emerged from private securitisers, often investment banks, which resulted in a market shift that lowered underwriting standards, as securitisers competed for market share, engaging in a "race to the bottom." ${ }^{.16}$ PLS were characterised by a different structure than the GSEs' MBS, as they did not benefit from (implicit) government backing to guarantee credit risk. In order to manage credit risk, they were tranched on that dimension, enabling investors to decide how much risk they were willing to take and, in theory, to be compensated for taking higher risk by higher spreads. ${ }^{17}$ Investors relied on rating agencies to establish the credit risk of PLS rather than the market because of the heterogeneity of mortgages within the PLS pools (McCoy, Pavlov and Wachter 2009).

This structure provided investment-grade ratings for most tranches of the security, attracting institutional capital in exchange for relatively low yields due to the expected safety of these tranches, as assessed by the rating agencies, while finding a way to manage the risk associated with the lower tranches. ${ }^{19}$ As private-label securitisation expanded in the number of securitisers, volume, and market share, and as the market itself expanded through lax underwriting and "affordable" products, more derivative products were created that expanded financing. ${ }^{20}$ These new financing vehicles contributed to the proliferation of non-traditional mortgages. There was an attempt at diversification since no securitiser was to have more than $5 \%$ of the market, which was relied on as a way to reduce risk. However, this so-called "diversification" did not in fact add to diversification since the twenty or so predominant securitisers were essentially securitising the same loans, geographically and in other dimensions.

Throughout most of their history, the GSEs had exercised control over the mortgage origination market, enforcing the conforming mortgage guidelines. As the dominant securitisers, they dictated terms to originators. If the originators did not comply, they would find themselves without a secondary market for their mortgages (Simkovic 2013). As a result, the years of GSE dominance were marked by the standardisation of mortgage products. Originators followed underwriting practices to ensure that their loans were "conforming" to the GSEs' requirements. If GSEs discovered that they had been sold loans that did not conform, they had a contractual right to sell the non-conforming loans back to the originator. In instances where originators 
repeatedly tried to game the system, the GSEs could and did put an end to their business relationship, a blow so severe that it put some originators out of business entirely. In order to enforce the repurchase agreements, the GSEs had to sample the loans for defects. Thus, securitisation did not prevent them from closely monitoring the risks of individual loans. Until the mid-2000s, the origination market was dominated by traditional long-term, fixed-rate mortgages, and the average borrower characteristics - low CLTV ratios, full documentationindicating that originators were upholding underwriting standards. For decades, this model proved sustainable.

But with the growing presence of private securitisers, the GSEs lost power over originators: if they threatened to cut off originators whose underwriting standards seemed too risky, the originators could simply go to a private label securitiser who would readily accept their product. Issuers were able to find investors for mortgage products that did not follow the GSEs standard guidelines. The GSEs and their regulator were charged with securitising safe and sound mortgages for the nation as a whole and in fact they did so for decades. The guidelines imposed by the GSEs had been the basis for national standards for mortgages, but they no longer held. The historical experience in the US of low default risk associated with securitisation of mortgages that represented nationally diversified portfolios could not be maintained as risky products and lax underwriting took over the market.

\section{Mortgage finance with externalities}

Systemic risk has been associated with excessive lending by "too big to fail" firms with moral hazard. But, systemic risk can also arise from individual lending decisions, in an interconnected system, by competitive firms that do not account for all the costs of default and foreclosure risk.

Three types of foreclosure externalities, not internalised by competitive firms, are:

1. Fire sale externalities: If a borrower defaults on a mortgage, the lender is likely to foreclose on the home. This foreclosure will depress the prices of nearby homes (Campbell, Giglio and Pathak 2011; Anenberg and Kung 2014), making it more likely the neighbours will default. More generally, an increase in supply of homes in a given 
market through foreclosure will depress housing prices (Zevelev 2014). Since no single lender lends to all homes in a market, individual lenders, especially if they are a small part of the market, will neglect these foreclosure externalities when making a mortgage contract. $^{21}$

2. Bank loss externalities: Banks that suffer losses from foreclosure are less capable of lending to new homebuyers. If potential homebuyers can't get mortgages, there is less demand for housing, further depressing house prices (Iacoviello 2005).

3. Borrower loss externalities: Similarly, borrowers who have "borrowed excessively" are less capable of future borrowing, again resulting in less demand for housing and depressed housing prices (Bianchi and Mendoza 2010 and Jeanne and Korinek 2010). ${ }^{22}$

If there were a "monopoly" lender in the economy, however, this lender would be more prudent because this lender would be exposed to aggregate credit risk. If one household defaults, this lender knows it will depress the prices of neighbouring homes and increase the likelihood that they will default. Note that a monopoly in this setting does not necessarily mean a single lender. Having a single regulator (e.g. Federal Housing Finance Agency, the regulator of the GSEs) requiring several or many lenders to play by the same rules could be functionally equivalent. A schematic representation of this set-up is shown in the accompanying box to illustrate the externality implications of varying market structures. With market demand for mortgages, a declining function of interest rates (given income), and with default risk and the social marginal cost of lending growing as the supply of debt increases relative to income, competitive lenders under-price risk. ${ }^{23}$ As debt levels increase (relative to income), the capacity to pledge collateral to pay back this debt decreases and the likelihood of higher default rates increases. The price of risk and the insurance premium should equal the marginal social cost of lending. But in the simplified framework, individual lenders perceive their cost of credit, including default risk, as constant, with the result that lending occurs beyond the socially optimal level.

The previous section described how the securitisation market shifted from a de facto regulated market to one in which private securitisation firms competed for mortgage product; from a market in which GSEs exercised significant control over mortgage origination with terms dictated to originators, to one in which non-traditional mortgage originators could access securitisation market funding without standardisation of mortgage products and without 
oversight of underwriting practices to ensure that their loans were "conforming" to the GSEs' requirements. With the end of this control, individual lenders and their investors without a view on the aggregate market could make loans without a consideration of growing aggregate risk.

In the build-up to the crisis, the market pricing of risk did not increase; the cost of funds appears to have been constant or even decreasing relative to Treasuries (Levitin and Wachter 2012; Davidson, Levin, and Wachter 2014). This was in the face of rising CLTV levels as well as higher expected probabilities of default based on product risk (for all mortgages, not just risky mortgages due to externalities, as noted above), although actual default rates remained suppressed at historically low levels due to increasing housing prices as a result of rising demand enabled by declining standards. Without an increase in the cost of credit and with a continuing decrease in lending standards, higher demand for housing resulted in higher housing prices, so that there was no warning in the form of heightened defaults of the crisis to come. Lending standards continued to decrease and the market continued to expand in the run-up to the crisis, until demand growth decelerated with the limits of easing reached.

Interesting but still unresolved questions are why market forces did not operate to prevent this and whether market mechanisms can be designed to improve the functioning of markets in the presence of lending externalities.

As debt increased, it would have been expected that lenders would have appreciated the increasing aggregate risk to some degree and price in higher risk premia. This did not occur. Misaligned incentives and moral hazard from too-big-to-fail and securitisation undoubtedly were part of the explanation for this outcome. ${ }^{24}$ Some investors understood that risk was increasing and famously and successfully created complex deals that shorted the market. But these investors were a small part of the market and did not raise the overall market pricing of risk, as would be expected if many investors attempted to sell such debt absent an increase in buyers. Moreover, as risk increases, housing prices should decline due to expectations of more foreclosures, rather than increasing relative to fundamentals. Generally the literature finds housing prices to be predictably mean-reverting. This suggests that frictions make it difficult to sell homes short when market prices are elevated beyond levels justified by fundamentals (Herring and Wachter 1999). ${ }^{25}$ 
The macro literature has developed models that explain the inefficiency of over-borrowing. For example, in a model developed by Jeanne and Korinek (2010), the ability to pledge collateral in the future is debased due to over borrowing and over lending which occurs because agents do not take account of the interdependencies of asset prices and lending conditions and the subsequent inability to pledge collateral and raise collateralised funds leads to a decline in the real economy.

But ultimately, these frictions could be overcome by short sellers, of the underlying housing asset, who are aware of market interdependencies, if short selling were possible. We have argued elsewhere (Pavlov and Wachter, 2009, and Levitin, Pavlov and Wachter 2012) that, in principle, new forms of securitisation could offer derivatives to complete the housing market, essentially enabling the equivalent of short sales. In effect, short selling of collateralised debt could, in theory, raise the cost of debt and lower housing prices, stopping the formation of bubbles. The financial accelerator would reverse, bursting an incipient bubble before dangerous levels of debt and prices are reached. Securitisation vehicles could be traded to price risk if they represented a standardised bundle of risk. The complexity and heterogeneity of securitisation offered by the private label market impeded such trading (Levitin and Wachter 2012). These securities were bespoke and did not trade. Tradable securities and information on aggregate market exposure to credit risk could assist in the market pricing of risk. ${ }^{26}$

But if lenders compete for market share and have heterogeneous expectations of and preferences for risk (Pavlov and Wachter 2006; 2009; and Lai and Van Order 2014)), the structure of the market will impact the production of risk. The change in the structure of the mortgage securitisation market in the US in the build-up to the crisis enabled a decline in lending standards that, in this case, was not observed. Deterioration in lending standards that are not monitored cannot be controlled. While the GSEs had served a gate-keeping function to maintain standards, the risk characteristics of private label securitisers' funded credit, in the aggregate, was remarkably neither known or arguably knowable in real-time, enabling the credit and price booms. While lenders and investors assumed either no increase in risk or that the risk could be off-loaded, in the end, through direct losses and through putbacks, lenders and investors were exposed to risk. Thus, for now and for the foreseeable future, the emphasis in housing finance will be on knowing and controlling credit risk. 


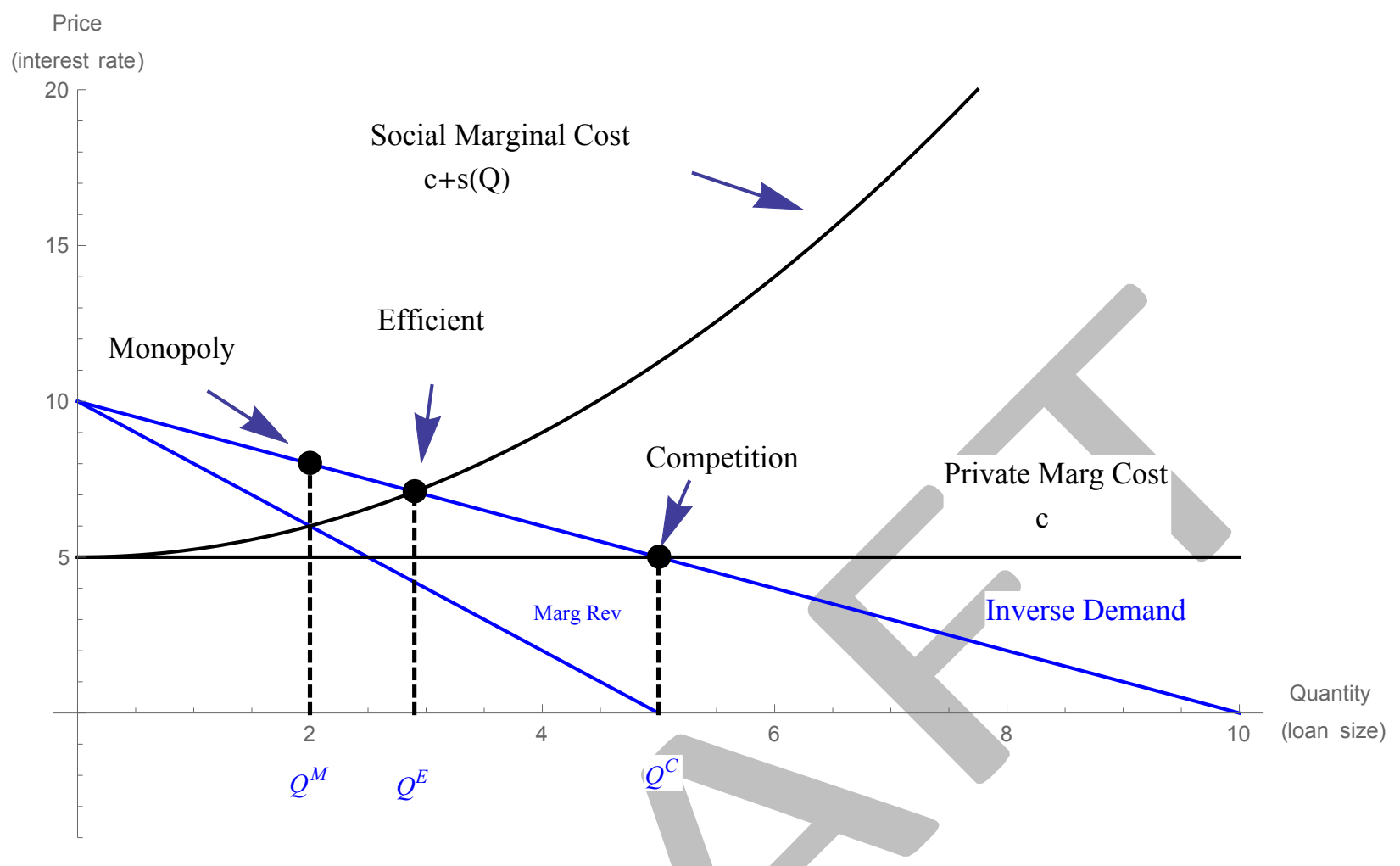

Observe that in a competitive mortgage market each lender chooses a loan size (to maximise profit) where marginal revenue is equal to the private marginal cost. However, it is well documented that leverage has negative externalities so there are social costs that competitive lenders neglect when choosing the optimal loan production.

\section{Conclusion}

In the US, there are a number of policy responses that are being considered in the aftermath of the crisis. In particular, the structure of a reformed mortgage securitisation market is being debated.

In the run-up to the housing crisis, beginning in the early 2000s, the structure of the mortgage backed securitisation (MBS) market shifted. Private label securitisers' MBS issuance began rising sharply, with most of the growth coming from non-traditional mortgages - non-amortising, with adjustable rates, and/or to riskier borrowers, as measured by standard underwriting criteria 
like CLTV ratios, and incomplete or no documentation. By the mid-2000s, the private-label MBS issuers had overtaken the GSEs as the dominant provider, as measured by their majority market share in mortgage securitisation. Prior to this, the GSEs and FHA provided insurance to most funders of MBS. While there is controversy as to what extent the lending standards of the GSEs themselves eased over time, there is no question that explosive growth occurred in low or zero documentation loans, teaser rate ARMS, as well as other aggressive lending products funded by non-GSE securitisation, to the point that at the peak of the bubble, non-traditional mortgages, largely funded by private-label MBS, were about $50 \%$ of origination volume. As the private-label MBS market share expanded, and the number of securitisation outlets increased, the origination process itself was affected, both in mortgage product composition and the quality of underwriting. Access to securitisation markets was assumed to allow all risk to be passed on to private label securities' investors, under banks "originate-to-distribute" business model.

A key reason for the increase in risky debt is that individual subprime lenders operating in a competitive market did not internalise the impact of their lending on aggregate risk. With de facto deregulation, lending occurred beyond what was socially optimal and risk became more concentrated in risky products- and systemic - rather than more diversified. Aggregate risk increased as the quality of the credit composition of the book of business deteriorated.

Regulated securitisers aware of their exposure to aggregate market risk have an incentive and capacity to enforce product standards on originators, while competition among securitisers, with heterogeneous risk preferences and market expectations, undermines the ability to enforce product-lending standards, resulting in a deterioration of the mortgage pool, Improvements in infrastructure to enable the monitoring and identification of aggregate credit risk are possible and ongoing in the context of the US. In addition, stress tests and other forms of micro and macro prudential policy in the oversight of banks, especially those regarded as systemically important financial institutions are ongoing. The Dodd Frank Act precludes some forms of risky mortgage lending and makes it costlier to offer so called non-qualified mortgages, a cost that limits their issuance for now but not necessarily in the longer run. But the restructuring of the securitisation market - the major regulatory issue in the US housing finance system, which depends upon securitisation - remains unfinished. 
Bipartisan proposed legislation, the Johnson-Crapo $\mathrm{Act}^{27}$ has come the closest to overcoming deep divisions in the understanding of what is necessary to restructure securitisation markets. The essence of the proposed JCA was to increase the role of private capital in a competitive setting to price risk and prevent excessive lending from occurring in the future, with the recognition that the cost of such capital would of necessity need to reflect higher expected credit risk. But the cost of capital is endogenous to the structure and regulation of the securitisation market. Thus, going forward, this more basic problem will need to be resolved as well.

\footnotetext{
${ }^{1}$ The existence of bubbles and how to detect them remains the subject of debate. For a definition based on the departure of asset prices from fundamentals, see Brunnermeier (2007). But see Cochrane (2011, p. 2), "Crying bubble is empty unless you have an operational procedure for distinguishing them from rationally low risk premiums." While efficient markets are thought to preclude bubbles (Fama 1970) with limited arbitrage, asset bubbles can emerge. Pavlov and Wachter (2004) show that under-priced credit can lead to inflated asset prices. ${ }^{2}$ In the originate-to-distribute model, the originator of a loan does not keep the loan on its balance sheet but rather sells the loan to a third party that will assume the interest rate and the credit risk.

${ }^{3}$ For differing views on the form these regulations should take, see Raskin (2013) and Cochrane (2013).

${ }^{4}$ Financial accelerator models have been developed to explain this. See Bernanke (1983), Bernanke and Gertler (1989), Herring and Wachter (1999), Almeida, Campello, and Liu (2006), and Dell'Ariccia, Igan, and Laeven (2012).

${ }^{5}$ After 2007, this fell to approximately $70 \%$. See Zevelev (2014).

${ }^{6}$ There is debate over whether rising prices lead to an increase in credit, or whether credit supply drives housing price appreciation. Jurgilas and Lansing (2013) find Granger causality in both directions.

${ }^{7}$ Federal Housing Administration (FHA) and Veteran Administration (VA) shares also shrunk. During the housing boom, subprime originators took market share away from the FHA and VA programs with loan features such as teaser rate and partial amortisation that made subprime loans more affordable initially. See note 10 and 11 for a history of these programs.

${ }^{8}$ Alt-A designates loans extended to borrowers whose credit score was near prime levels but who lacked full verification. During the housing boom, Alt-A loans were unwritten based on the borrower's "stated" income; after the financial crisis these became known as liar loans.

${ }^{9}$ From 1968 to 2008 , this government backing was implicit. The GSEs were private corporations, not public agencies, although their charters' conservatorship provision meant that the government would not let them fail in times of distress. In 2008, the Federal Housing Finance Agency, their regulator, took them into conservatorship, making their government backing explicit.

${ }^{10}$ These entities formed the basis for the modern US housing finance system. The guidelines developed by the Home Owners' Loan Corporation (HOLC) (created in 1933) and then FHA (that replaced it in 1936) led to the emergence of the long-term, fixed-rate mortgage with low down payment, full amortisation, and no prepayment
} 
penalty as the most common product (Green and Wachter 2005). In addition, in 1944, the GI Bill created the Veterans Administration (VA) mortgage insurance program, which offers loans with affordable features to veterans. Fannie Mae started purchasing VA-insured loans in 1948, a function taken over by Ginnie Mae after 1968, which continues to securitise FHA and VA loans.

${ }^{11}$ The government split Fannie Mae into two institutions: the Government National Mortgage Association (Ginnie Mae) that continued to purchase FHA/VA mortgages, and a privatised Fannie Mae that was allowed to purchase conventional mortgages (not government-insured) to assist in the purchase of mortgages and recovery of the S\&L industry (Levitin and Wachter 2013c). Fannie Mae and later Freddie Mac enabled commercial banks and S\&Ls to move mortgages off balance sheets as long as they were conforming (long-term, fixed-rate, self-amortising) mortgages that met the GSEs underwriting criteria.

${ }^{12}$ This enabled institutional investors to invest in securities in which they were able to manage the interest rate risk they were taking while Freddie Mac conserved the credit risk. This model of securitisation was followed by Fannie Mae in 1981.

${ }^{13}$ Through the TBA market, the GSEs are able to set an interest rate before purchasing the mortgages from originators, allowing lenders to "lock in" rates before issuing the loan. The substitutability of mortgages within TBA pools contributes to the liquidity of the market.

${ }_{15}^{14}$ See endnotes 10 and 11 for further discussion of Ginnie Mae.

${ }^{15}$ There is a controversy over to what degree the conforming standards changed over time. See Pinto (2011), Keys et al (2010), Simkovic (2013), and Thomas and Van Order (2013),

${ }^{16}$ PLS began with the securitisation of jumbo loans, prime loans for amounts larger than the GSE's conforming size limit, providing liquidity to a segment of the market that was not eligible for purchase by the GSEs. The jumbo mortgages in these early PLS were characterised by low LTVs (Green and Wachter 2005).

${ }^{17}$ In the originate-to-distribute model, lenders have an incentive to maximise origination fees and are assumed not to have a vested interest in the performance of the mortgages they sell to securitisers. They therefore are focused on the short-term fee income rather than on the long-term performance of the mortgages underlying the pool. While misaligned incentives and short-term performance goals may very well have had a part to play (Pavlov and Wachter 2006), many of the securitising entities, as well as the originating entities of NTMs, did keep these mortgages on their balance sheets (Bubb and Krishnamurthy 2014). In the aftermath of the crisis, these loans were subject to putbacks when it was determined that loan terms were misrepresented.

${ }^{18}$ Rating agencies gave low risk ratings in part because the loan pools were diversified (Vinokurova 2011). See Beltran, Cordell and Thomas (2013) for the role of rating agencies and asymmetric information in the development of Collateralized Debt Obligations (CDOs), derivatives that increase the supply of credit.

${ }^{19}$ See Levitin and Wachter (2012).

${ }^{20}$ Rules such as the SEC relaxation of leverage ratios and capital controls for investment banks in 2004 enabled private securitisers to issue more PLS with the same amount of capital. Additionally, credit default swaps (CDS) were exempted from reserve through the Commodities Exchange Act in 2000 (CDS are instruments that can be used to hedge against the default risk) See McCoy, Pavlov and Wachter 2009.

${ }^{21}$ Note that the fire sale externality is a type of pecuniary externality because it operates through prices. See Bianchi and Mendoza 2010 for a discussion of how over-borrowing creates a pecuniary externality through the fire sale mechanism. Borrowers undergoing foreclosure don't maintain their homes, further reducing the house's value as well as those of nearby homes (Melzer 2012).

${ }^{22}$ These studies show how households do not internalise how asset prices used for collateral respond to borrowing decisions.

${ }^{23}$ See Davidson, Levin, and Wachter (2014) for evidence of underpriced risk in the run-up to the financial crisis. Pavlov and Wachter (2008) discuss correlation of underpricing of risk with house price appreciation (all else equal) as an indicator of a bubble as defined in note 1 .

${ }^{24}$ Lending to accumulate short-term profits without regard to long-term performance due to fee-based compensation played a role, as did credit default swaps that allowed insurance against defaults at cheap rates while investing in these mortgages at higher rates. And short-term profit-taking and limited liability of firm shareholders played a role. The originate-to-distribute model exacerbated these incentive problems since originators assumed that risk could be off-loaded. But this cannot be a complete explanation of the crisis since many subprime originators kept mortgages on their balance sheets. Moreover it leaves the question of why investors provided funding to securitisers (subsequently to be wiped out) unanswered (Pavlov and Wachter, 2006).

${ }^{25}$ In the absence of such frictions, individuals could short sell their homes and then buy them back more cheaply, causing prices to fall back to fundamental levels if unduly elevated. But of course this is not possible. Indeed, 
without the potential to sell real estate short, the lower price of debt led to more demand on the part of speculators, as a means of short selling the asset through exercising the option to put the property back to the lender, with nonrecourse loans.

${ }^{26}$ Although, it should be noted that transparency is not a panacea, and at the scale of specific geographic markets, could be counterproductive (Pavlov, Wachter and Zevelev, forthcoming).

${ }^{27}$ Johnson - Crapo S.1217, http://www.crapo.senate.gov/issues/banking/housing_finance_reform.cfm.

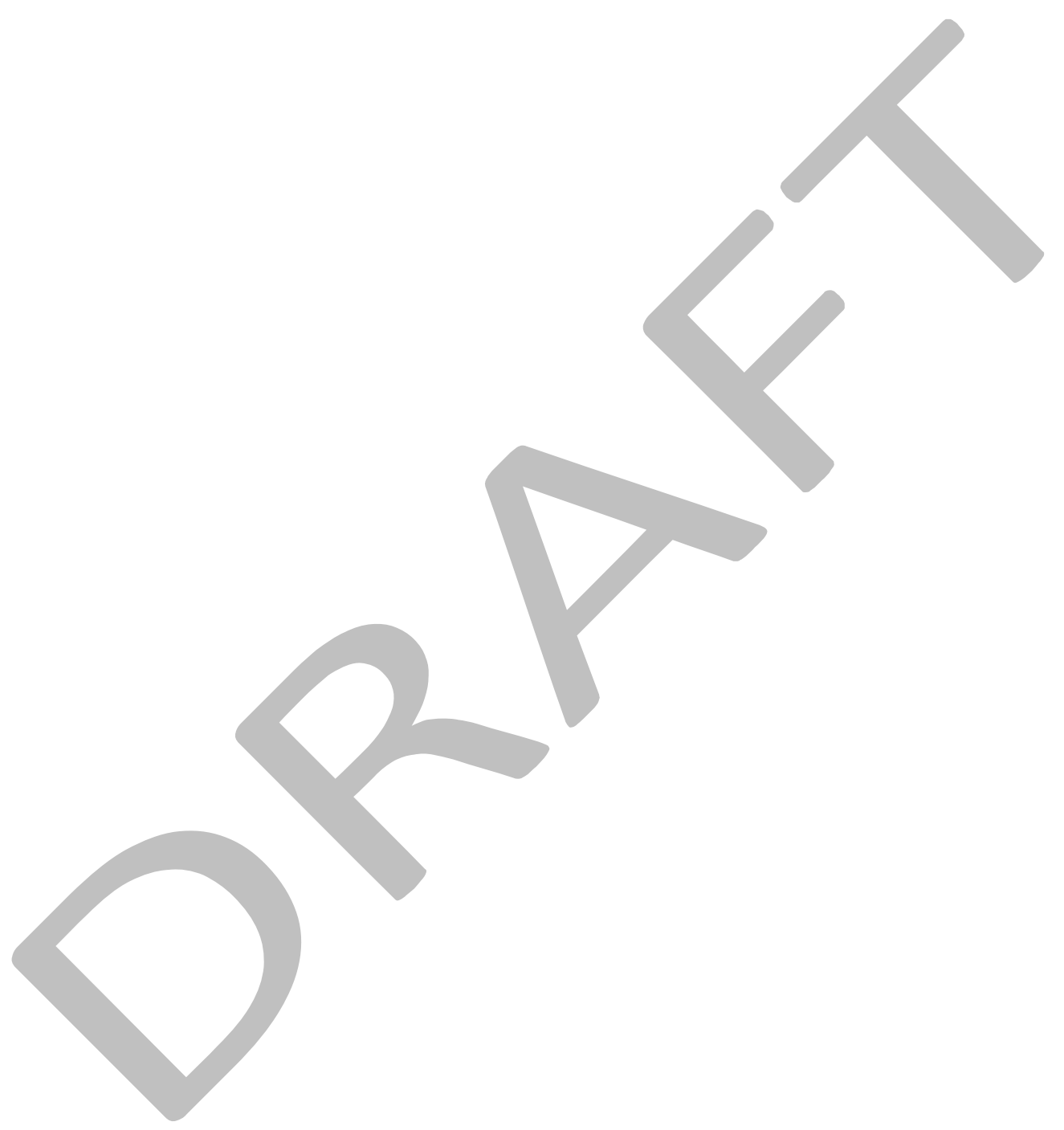




\section{References}

Almeida, H, Campello, M. and Liu, C. (2006), 'The financial accelerator: evidence from international housing markets', Review of Finance 10(3), pp. 321-352.

Anderson, C. D., Capozza D. R., and Van Order, R. (2011), 'Deconstructing a Mortgage Meltdown: A Methodology for Decomposing Underwriting Quality', Journal of Money, Credit, and Banking, 43(4), pp. 609-631.

Anenberg, E. and Kung, E. (2014), 'Estimates of the Size and Source of Price Declines Due to Nearby Foreclosures', American Economic Review, 104(8), pp. 2527-51.

Barakova, I., Calem, P. S. and Wachter, S. M. (2014), 'Borrowing Constraints during the Housing Bubble', Journal of Housing Economics, 24, pp. 4-20.

Beltran, D. O., Cordell, L., and Thomas C. P. (2013), 'Asymmetric Information and the Death of ABS CDOs', International Finance Discussion Paper, http://www.federalreserve.gov/pubs/ifdp/2013/1075/.

Bernanke, B. (1983), 'Nonmonetary Effects of the Financial Crisis in the Propagation of the Great Depression', American Economic Review, 73.

Bernanke, B. and Gertler, M. (1989), 'Agency Costs, Net Worth, and Business Fluctuations', The American Economic Review, 79(1), pp. 14-31.

Bianchi, J., and Mendoza, E. (2010), 'Overborrowing, Financial Crises, and "Macroprudential" Taxes', Working Paper 16091. NBER, http://www.nber.org/papers/w16091

Brunnermeier, M. K. (2008), 'Bubbles', The New Palgrave Dictionary of Economics, 2.

Bubb, R. and Krishnamurthy, P. (forthcoming), 'Regulating Against Bubbles: How Mortgage Regulation Can Keep Main Street and Wall Street Safe', University of Pennsylvania Law Review.

Campbell, J. Y., Giglio, S. and Pathak, P. (2011), 'Forced Sales and House Prices', American Economic Review, 101(5), pp. 2108-31. 
Cochrane, J. H. (2011), 'How did Paul Krugman get it so wrong?' Economic Affairs, 31(2), pp. $36-40$.

Cochrane, J. H. (2013), 'Macro-prudential policy', The Grumpy Economist, http://johnhcochrane.blogspot.com/2013/08/macro-prudential-policy.html.

Davidson, A., Levin A. and Wachter, S. (2014), 'Mortgage Default Option Mispricing and Procyclicality', Homeownership Built to Last: Balancing Access, Affordability, and Risk after the Housing Crisis, eds. Belsky E. S., Herbert C. E., and Molinsky J. H., Cambridge, MA: Brookings Institution Press and the Harvard University Joint Center for Housing Studies, pp. 290-316.

Dell'Ariccia, G., Igan, D. and Laeven, L. (2012), 'Credit booms and lending standards: Evidence from the subprime mortgage market', Journal of Money, Credit and Banking, 44(2-3), pp. 367-384.

Fama, E. F. (1970), 'Efficient capital markets: A review of theory and empirical work', The Journal of Finance, 25(2), pp. 383-417.

Federal Reserve Bank, Flow of Funds, http://www.federalreserve.gov/apps/fof.

The Financial Crisis Inquiry Commission (2011), 'The Financial Crisis Inquiry Report: Final Report of the National Commission on the Causes of the Financial and Economic Crisis in the United States', Washington, D.C.: US Government Printing Office.

Green, R. K. and Wachter, S. (2005), 'The American Mortgage in Historical and International Context', Journal of Economic Perspectives, 19(4), pp. 93-114.

Herring, R. J. and Wachter, S. (1999), 'Real Estate Booms and Banking Busts: An International Perspective', Group of Thirty, Occasional Papers.

Iacoviello, M. (2005), 'House prices, borrowing constraints, and monetary policy in the business cycle', American economic review, pp. 739-764.

Jeanne, O., and Korinek, A. (2010) 'Managing Credit Booms and Busts: A Pigouvian Taxation Approach', Working Paper 16377. NBER, http://www.nber.org/papers/w16377. 
Jurgilas, M. and Lansing, K. J. (2013), 'Housing Bubbles and Expected Returns to Homeownership: Lessons and Policy Implications', Property Prices and Real Estate Financing in a Turbulent World, eds. Balling, M. and Berg, J., Vienna: SUERF, pp. 101-128.

Keys, B. J., Mukherjee, T., Seru, A., Vig, V., and Kolb, R. W. (2010), 'Did Securitization Lead to Lax Screening? Evidence from Subprime Loans', Lessons from the Financial Crisis:

Causes, Consequences, and Our Economic Future, ed. Kolb, R., Hoboken, NJ: John Wiley \& Sons, pp. 217-224.

Lai, R. N., and Van Order, R. (2014). 'Securitization, Risk-Taking and the Option to Change Strategy. Real Estate Economics', 42(2), pp. 343-362.

Levitin, A. J., Pavlov, A. D., and Wachter, S. M. (2012), 'Will Private Risk-Capital Return? The Dodd-Frank Act and the Housing Market', Yale Journal on Regulation, 29(1), pp. 155-180.

Levitin A. and Wachter, S. (2012), 'Explaining the Housing Bubble', Georgetown Law Journal, 100(4), pp. 1177-1258.

Levitin, A. and Wachter, S. (2013a), 'Why Housing?' Housing Policy Debate.

Levitin, A. and Wachter, S. (2013b), 'The Commercial Real Estate Bubble," Harvard Business Law Review.

Levitin, A. and Wachter S. (2013c), 'The Public Option in Housing Finance," U.C. Davis Law Review.

McCoy, P., Pavlov, A. and Wachter, S. (2009), 'Systemic Risk Through Securitization: The Result of Deregulatory and Regulatory Failure', Connecticut Law Review, 41, pp. 1327-1375.

Melzer, B. (2012), 'Mortgage debt overhang: Reduced investment by homeowners with negative equity', Northwestern University.

Mian, A. and Sufi, S. (2014), House of Debt: How They (and You) Cause the Great Recession, and How We Can Prevent It from Happening Again, Chicago, IL: Chicago University Press.

Pavlov, A. and Wachter, S. (2004), 'Robbing the Bank: Non-recourse Lending and Asset Prices', Journal of Real Estate Finance and Economics, 28(2-3), pp. 147-160. 
Pavlov, A. and Wachter, S. (2006), 'The Inevitability of Market-Wide Underpriced Risk', Real Estate Economics, 34(4), pp. 479-496.

Pavlov, A. and Wachter, S. (2008), 'Mortgage Put Options and Real Estate Markets', Journal of Real Estate Finance and Economics, 36(2), pp. 231-239.

Pavlov, A. and Wachter, S. (2009), 'Systemic Risk and Market Institutions', Yale Journal on Regulation, 26(1), pp. 445-455.

Pavlov, A., Watcher, S., and Zevelev, A. (forthcoming), 'Transparency in the Mortgage Market', Journal of Financial Services Research.

Pinto, E. J. (2011), 'Government Housing Policies in the Lead-Up to the Financial Crisis: A Forensic Study', Working Paper, http://www.aei.org/files/2011/02/05/Pinto-GovernmentHousing-Policies-in-the-Lead-up-to-the-Financial-Crisis-Word-2003-2.5.11.pdf.

Raskin, S. B. (2013), 'Beyond Capital: The Case for a Harmonized Response to Asset Bubbles', Speech at The Exchequer Club Luncheon, Washington, DC, http://www.federalreserve.gov/newsevents/speech/raskin20130717a.htm.

Scheinkman, José A. (2013), 'Speculation, trading and bubbles', Third Annual Arrow Lecture, Available at http://www.princeton. edu/ joses/wp/Arrow.pdf.

Simkovic, M. (2013), 'Competition and Crisis in Mortgage Securitization', Indiana Law Journal, $88, \mathrm{pp} .213$.

Thomas, J. and Van Order, R. (2013), 'The Collapse of Fannie Mae and Freddie Mac: A Study in Risk-Taking', Working Paper, George Washington University.

Vickery, J. and Wright J. (2013), 'TBA Trading and Liquidity in the Agency MBS Market', Federal Reserve Bank of New York Economic Policy Review.

Vinokurova, N. (2011), 'The 2008 Mortgage Crisis as a Failure of Analogical Reasoning', Working Paper, New York University.

Wachter, S. (forthcoming), 'The Housing and Credit Bubbles in the US and Europe: A Comparison', Journal of Money, Credit and Banking. 
Yellen, J. L. (2010), 'Macroprudential Supervision and Monetary Policy in the Post-crisis World', Speech given at the Annual Meeting of the National Association for Business Economics, Denver, Colorado, (October 11, 2010).

Zevelev, A. (2014), 'Regulating Mortgage Leverage: Fire sales, Foreclosure Spirals and pecuniary externalities', Working Paper.

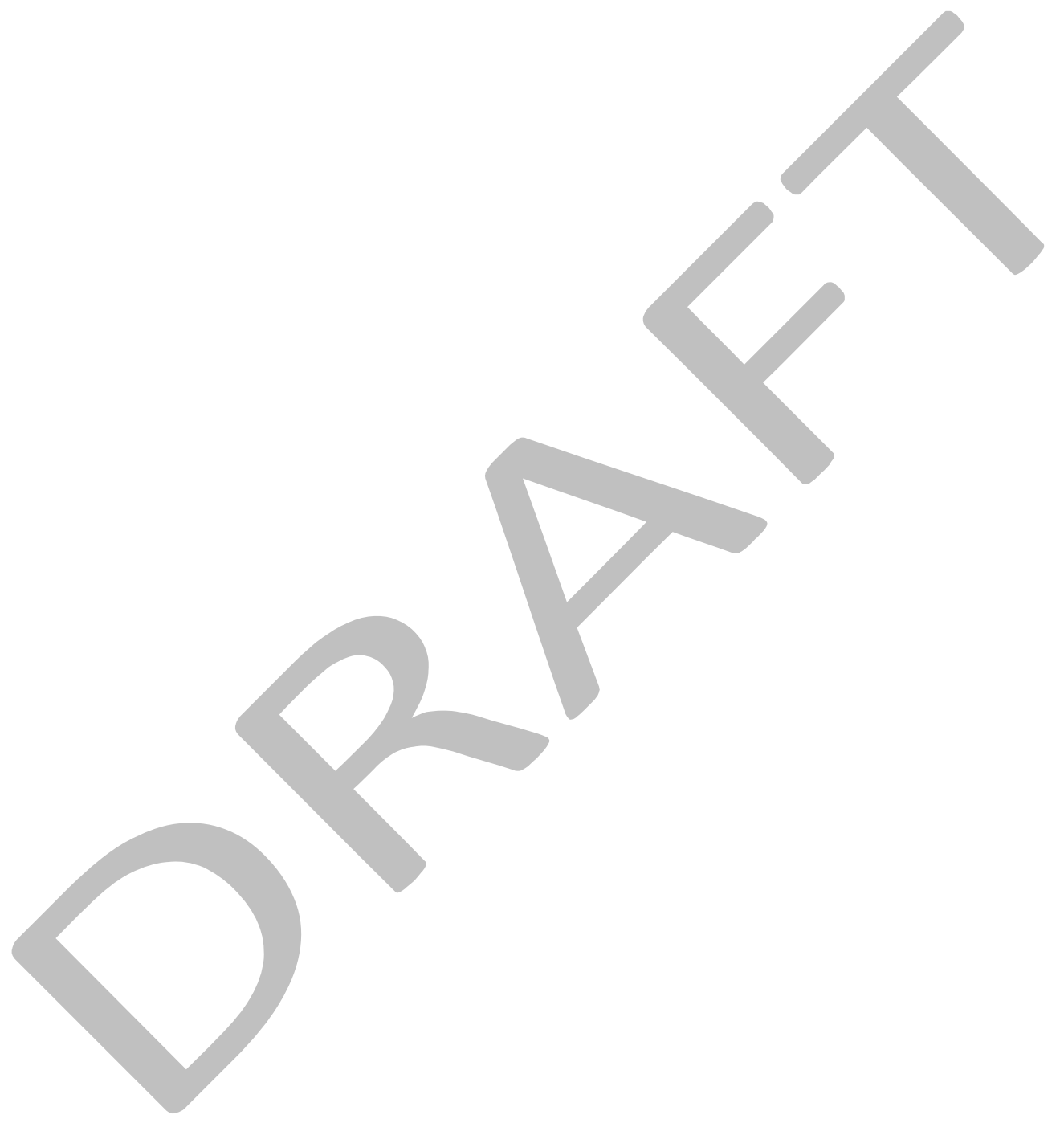

